\title{
Author Correction: Continent-wide tree fecundity driven by indirect climate effects
}

James S. Clark (1), Robert Andrus, Melaine Aubry-Kientz, Yves Bergeron (1D, Michal Bogdziewicz (D), Don C. Bragg, Dale Brockway, Natalie L. Cleavitt, Susan Cohen, Benoit Courbaud, Robert Daley, Adrian J. Das (D,

Michael Dietze, Timothy J. Fahey, Istem Fer, Jerry F. Franklin, Catherine A. Gehring, Gregory S. Gilbert (1D, Cathryn H. Greenberg, Qinfeng Guo (D), Janneke HilleRisLambers, Ines Ibanez (D, Jill Johnstone, Christopher L. Kilner (D), Johannes Knops, Walter D. Koenig (D), Georges Kunstler, Jalene M. LaMontagne (D), Kristin L. Legg, Jordan Luongo, James A. Lutz (D), Diana Macias, Eliot J. B. Mclntire, Yassine Messaoud, Christopher M. Moore, Emily Moran, Jonathan A. Myers (D), Orrin B. Myers, Chase Nunez (D), Robert Parmenter (1), Sam Pearse, Scott Pearson (1), Renata Poulton-Kamakura, Ethan Ready, Miranda D. Redmond, Chantal D. Reid, Kyle C. Rodman (1), C. Lane Scher, William H. Schlesinger, Amanda M. Schwantes, Erin Shanahan, Shubhi Sharma, Michael A. Steele, Nathan L. Stephenson (1D, Samantha Sutton, Jennifer J. Swenson, Margaret Swift, Thomas T. Veblen (1D, Amy V. Whipple,

Thomas G. Whitham, Andreas P. Wion, Kai Zhu (1) \& Roman Zlotin

Correction to: Nature Communications https://doi.org/10.1038/s41467-020-20836-3, published online 23 February 2021.

The original version of this Article contained an error in Equation (1). The equation incorrectly included a “+” sign within the "growth-climate interactions" term. This has now been corrected in both the PDF and HTML versions of the Article.

Published online: 08 March 2021

Open Access This article is licensed under a Creative Commons Attribution 4.0 International License, which permits use, sharing, adaptation, distribution and reproduction in any medium or format, as long as you give appropriate credit to the original author(s) and the source, provide a link to the Creative Commons license, and indicate if changes were made. The images or other third party material in this article are included in the article's Creative Commons license, unless indicated otherwise in a credit line to the material. If material is not included in the article's Creative Commons license and your intended use is not permitted by statutory regulation or exceeds the permitted use, you will need to obtain permission directly from the copyright holder. To view a copy of this license, visit http://creativecommons.org/licenses/by/4.0/.

(c) The Author(s) 2021 